Agata Skała

Uniwersytet im. Marii Curie-Skłodowskiej w Lublinie*

\title{
O wartości literatury w świetle aforyzmów i korespondencji Adolfa Dygasińskiego
}

\author{
On the Value of Literature in the Light of Adolf Dygasiński's Aphorisms \\ and Correspondence
}

\begin{abstract}
Adolf Dygasiński methodically developed writing meticulous aphorisms. He cherished the intention to write a vast theoretical study on literature, author, reader and the book. The sketched adages were to help him as central themes for particular chapters. Although the substantial part of this collection is characterized by stylistic negligence (the indicator of a sketch) there exists the need for a thorough inspection of the senses of aphorisms, as they include prudent and maturely thought over concepts that show the writer's own project, which has not been expressed anywhere else by a systemic lecture and concerned the significance of literariness. Together with journalistic texts and private letters, aphorisms constituted the testimony of Dygasiński's creative awareness.
\end{abstract}


* Zakład Literatury Pozytywizmu i Młodej Polski Pl. Marii Curie-Skłodowskiej 4A, 20-031 Lublin e-mail: agaskala@hektor.umcs.lublin.pl 
„Każda literatura, choćby bardzo stronna, zawsze wyższa od życia społecznego. Literatura ma od Boga pełnomocnictwo sądzić" (Dygasiński 1953a: 223) ${ }^{1}$. Gdyby wypowiedź tę pozostawić bez odsyłacza informującego o autorstwie, zrazu można by pomyśleć, że pomysłodawcą konceptu jest ktoś hołdujący wyobrażeniu pojmowania sztuki literackiej jako Absolutu lub że akt twórczy kojarzy się z doświadczeniem mistycznym (bez utożsamiania obu ezoterycznych procesów), a prawda objawiona w efekcie tego szczególnego poznania jest tożsama z wiedzą Boga. W takim kontekście dziwiłoby faktyczne autorstwo prezentowanej sentencji, zważywszy na fakt, że jej twórca w powszechnie funkcjonujacych opiniach krytyków i historyków literatury uchodzi za pisarza skupionego na życiu społecznym, na opisie praw rządzących w obrębie świata ludzkiego i zwierzęcego oraz że pojęcie „Boga” zupełnie nie przystaje do jego twórczości. W istocie jednak aforystycznie wyrażona idea o bliskości praw literackich prawom „boskim” przewrotnie wyraża to, co postulowali teoretycy pozytywizmu: celem literatury jest kształcenie etycznych postaw, doskonalenie społeczeństwa, urzeczywistnianie dobra (koncepty stanowiące podstawę programu utylitaryzmu). Piotr Chmielowski, rzecznik tendencyjności, w artykule pt. Jeszcze o celu w sz̨tuce, powołując się na rozpoznanie Hegla o sztuce jako stadium prowadzacym ducha bezwzględnego do zupełnej samowiedzy, przekonywał o celowości sztuki pisarskiej, podkreślając jej rolę w nauczaniu i wskazywaniu ,szczytów moralnych” za pośrednictwem „pięknych kształtów wcielających piękne idee” (Chmielowski 1904). Status pisarza konstytuowała służba na rzecz powszechnej użyteczności (Chmielowski 1872). W tym paradygmacie pisarz stawał się najwyższą instancją i, wolno przypuszczać, jego misja mogła być konceptualizowana nawet w metaforze Boga ${ }^{2}$.

Na wstępie należy zaznaczyć, że dyskusyjna mogłaby okazać się taka postawa wobec tekstu, która przyzwalałaby na traktowanie sensów w nim zawartych z dystansem, tzn. z nieufnością albo pobłażliwie — przy założeniu, że niewiele taki tekst (jak zacytowana maksyma) znaczyć może w przypadku, gdy znajduje się pośród pokaźnej ilości „innych”,

1 Znaczna część aforyzmów Dygasińskiego została opublikowana po jego śmierci przez Zofię Dygasińską-Wolertową, córkę, m.in. w „Gazecie Literackiej” w 1932 i w „Pionie” w 1934.

2 Jest niewattpliwe, że tak jak Chmielowski, wierny przez całe życie tendencyjno-utylitarnej teorii literackiej, tak i Dygasiński, związany przyjaźnią z Chmielowskim, nie zanegował nigdy utylitaryzmu i tendencyjności w jego podstawowych założeniach. 
prezentujących odmienne perspektywy oglądu rzeczy. Faktem jednakże jest, że przytoczony na początku tego artykułu aforyzm w istocie (gdy potraktować go jako wykładnię tendencyjno-utylitarnej idei) nie wykazuje sprzeczności ani z dziełami fabularnymi Dygasińskiego, ani z jego poglądami przedstawianymi w tekstach publicystycznych, jakkolwiek chyba tylko w Godach życia dałoby się znaleźć jasno wyłożone sugestie pojmowania sztuki jako służby bożej — z poprawką jednakże taka, że imputowanie pisarzowi tego poglądu z góry należałoby odrzucić jako nadużycie interpretacyjne, zważywszy na fakt, iż rzecznikiem owej myśli jest bohater powieści — ptaszek, poeta-kapłan, głoszący pieśnią piękno miłosierdzia, a powołany do pełnienia swej misji przez boga Słońce — Jasnego (Skała 2012) ${ }^{3}$.

Sentencje Adolfa Dygasińskiego godzi się przyjmować bardzo poważnie, gdyż nie stanowią wyłącznie rozproszonego katalogu, kompilowanego z fragmentów utworów objętościowo większych, beletrystycznych lub dziennikarskich. Przesadne koncentrowanie się na domyśle, że większość była pisana okazjonalnie ani niczego nie wyjaśni, ani też o niczym nie rozstrzyga. Zwykle bywa, że maksymy stanowią incydentalną, często wręcz uboczną formę ekspresji twórczej pisarza (wyjątkiem są przypadki autorów specjalizujących się w tego typu gatunkach), notowane na marginesach opracowywanych pomysłów dotyczących np. zdarzeń fabularnych, charakterystyki postaci literackich czy prezentacji tła społecznego lub psychologicznego świata przedstawionego. Gdy chodzi o Dygasińskiego, nie ulega wątpliwości, że z głębszym zamysłem traktował swoje zwięzłe formuły, których istota — z założenia — ma być błyskotliwość rzeczowego ujęcia spraw doniosłych ${ }^{4}$. Dygasiński metodycznie kolekcjonował tę „drobiazgową” twórczość. Według przekazu Zofii Dygasińskiej-Wolertowej (Dygasińska-Wolertowa 1932: 26), nosił się z zamiarem napisania obszernego studium teoretycznego na temat literatury, autora, czytelnika i książki ${ }^{5}$. Szkicowane sentencje miały mu być pomocne jako myśli przewodnie do poszczególnych rozdziałów. Należy zatem uznać, że jakkolwiek może na owych tekstach ciążyć piętno niedopracowania stylistycznego (wyznacznik „,szkicu”) ${ }^{6}$, istnieje potrzeba wnikliwego przyglądania się ich sensom, ponieważ zawierają w sobie rozważne i przemyślane koncepty, które, zestawione razem, unaoczniają niewyłożony nigdzie za pomocą systemowego wykładu własny projekt pisarza dotyczący istoty literatury i literackości. Na ich podstawie przyjdzie więc rekonstruować (biorąc pod uwagę również poetykę immanentną, wyniesiona z percepcji odbioru dzieł literackich) program artystyczny pisarza. Wraz z listami, poruszającymi tematy z zakresu literatury i literackości, aforyzmy stanowią świadectwo twórczej świadomości Dygasińskiego.

3 I nie bez znaczenia, oczywiście, są w tym kontekście zawarte w Godach jyycia przesłanki, które pozwalają widzieć w strzyżyku, „czcicielu światła” — wyznawcę Chrystusa.

4 To, co nazywam „błyskotliwością ujęcia” odnosi się bardziej do struktury aforyzmu niż do jego treści, która, ograniczona konieczną zwięzłością, musi w jakiejś mierze perswadować komunał, ogólną prawdę o charakterze np. filozoficznym. Tę skrótowość sentencji, będącą efektem stylistycznej wyrazistości, celnie precyzuje współczesny aforysta Ryszard Podlewski w stwierdzeniu: „Aforyzm to fast food filozofii” (Podlewski 2006).

5 Teoretyczna świadomość Dygasińskiego prezentują listy jego do przyjaciół: Stanisława Witkiewicza i Artura Gruszeckiego.

6 Nie dotyczy to tych ,złotych myśli”, które autor osobiście kierował do druku. 
Prowadzenie badań w tym zakresie wydaje się pożądane, aby ostatecznie zanegować takie błędne rozpoznania (w ostatnich latach nieraz już pokazywano ich zdezaktualizowanie), jakoby autor Zajaca był artystą samorodnym", ,genialnym barbarzyńcą" w świecie literackim $^{8}$, w znaczeniu: oryginałem, który nie korzystał z dorobku cywilizacji artystycznej, europejskiej czy polskiej, lub że brakowało mu literackiej ogłady ${ }^{9}$. Ponieważ wattpliwości na temat rzekomych słabości pisarstwa Dygasińskiego próbowano wykładać w innych miejscach (Bielak 1925; Szweykowski 1938; „Litteraria Copernicana” 2009; Skała 2013), tu pozostaje skoncentrować się na tym przede wszystkim, co zapowiada tytuł szkicu: czym jest literatura i co stanowi o jej wartości oraz jaki jest jej status w obrębie dziedzin życia społecznego i w rozwoju cywilizacyjnym.

Zagadnienia te zajmują w refleksji krytycznej Adolfa Dygasińskiego dobrze wyeksponowana pozycję. Pisarz na pewno wierzył w misję literatury w kwestii ulepszania świata, skoro formułował taką myśl: „, , jak dużo dla ludzkości pracowano, a jak mało zrobiono! Rzadkie są arcydzieła” (Dygasiński 1953a: 223). I apelował do autorów: „Uwrażliwiajcie ludzi, a będą dobrze czytali, mówili, pisali i działali” (Dygasiński 1953a: 224). Od pisarzy spodziewał się wyobraźni: „Literatury nie może przepisywać żadna kancelaria” (Dygasiński 1953a: 223) oraz niezależności myślowej i nieschlebiania czytelnikom: „Hałasy, wrzaski literackie przebrzmią, zostanie to, co jest dobre, piękne, szlachetne istotnie” (Dygasiński 1953a: 223). Z sarkazmem wypowiadał się Dygasiński o autorach skomercjalizowanych: „Głupota głęboka przybiera nieraz ton dramatyczny, aby ogłosić światu jego najulubieńsze brednie. I takim jest dobrze" (Dygasiński 1953a: 223). Ufał w walor twórczości bezpretensjonalnej, zrodzonej z wewnętrznej dyspozycji skierowanej na poszukiwanie prawdy. Z przekonaniem konstatowal:

Nikt tak dobrze, dokładnie nie zagląda we własną duszę, jak rzeczywisty artysta. Dobrze dla niego, gdy spostrzeże, że wśród ludzi chodzi w masce. Tajemnica jego roboty często na tym polega. Podpatrzeć siebie jest to warunek podpatrywania całej natury. (Dygasiński 1953a: 224-225)

Zrozumienie siebie stanowi podstawowe kryterium poznania prowadzące do wiedzy ogólnej — o człowieku i świecie ${ }^{10}$. Dla artysty to zrozumienie powinno być zasadnicze. Twórca musi bowiem przede wszystkim pojmować, że winien robić tylko to, co dla niego ma wartość, przy założeniu, że jeśli przypadkiem będzie to korzystne jeszcze dla kogoś innego — wówczas zostanie zrealizowany wzorzec działania artystowskiego. W prawidłowości takiego mniemania Dygasiński utwierdzał córkę, tłumacząc: „Otóż tylko dla siebie samej

7 Takie stanowisko reprezentował monografista Dygasińskiego Kazimierz Czachowski: „Dygasiński był — jak wiadomo — naturalista, ale nie z racji jakiegoś programowego założenia, lecz po prostu stąd, że nie brał on nic z drugiej ręki, że w jego utworach nie ma śladu jakichś obcych nalotów literackich, że czerpał on pomysły i obrazy z bezpośredniej obserwacji przyrody i życia i tego, co sam widział i samodzielnie w myśli swej przetrawił. Pod tym względem Dygasiński był najszczerszym autentystą" (Czachowski 1939).

8 To opinia, do której przekonywało wielu badaczy; jej źródłem był komentarz Antoniego Sygietyńskiego zawarty w prywatnym liście do przyjaciela (Korespondencja Antoniego Sygietyńskiego i Piotra Chmielowskiego 1963: 207).

9 Przekonanie takie popularyzował Henryk Markiewicz (2002: 177).

10 Chociaż znaczącą była idea samopoznania dla Dygasińskiego, bywał przekorny wobec samego siebie: „Moim zdaniem zasada poznawania siebie, postawiona jako coś nadzwyczajnego przez filozofów, jest kapitalnie głupią łamigłówką, nie mającą ani teoretycznego, ani praktycznego znaczenia. Człowiek wtedy poznaje siebie, kiedy musi, a z pewnością nikogo lepiej od siebie nie zna.” (Dygasiński 1972: 349). 
możesz robić, jeśli chcesz zrobić coś dobrego. Robiąc dla świata, nie zrobisz nic nigdy" (Dygasiński 1972: 386) ${ }^{11}$. Można z powyższego wnioskować, że od literatury pisarz wymagał tego, aby ona była moralna, tzn. rodziła się w postawie uczciwości pisarza względem jego aktywności twórczej i dzieła, które miało być efektem tych starań. Tylko taka postawa gwarantuje prawdę uczucia i przeżycia, realizując ideał sztuki jako potrzeby ekspresji, wyrażania niezależności i wolności twórczej ${ }^{12}$.

W twórczości Dygasińskiego rozpoznania wywiedzione z obserwacji natury własnej i ogólnej nie nastrajają optymistycznie. Na kondycję człowieka pisarz patrzył bez złudzeń. Żywił przekonanie, że ,istota zdolna do najwyższego wyobrażania sobie szczęścia jest jednocześnie najnieszczęśliwszym na świecie stworzeniem” (Dygasiński 1953b: 285) ${ }^{13}$. Nie jest to sąd oryginalny. Jego korzenie tkwią głęboko w europejskiej tradycji. To przecież u Homera spotykamy stwierdzenie, że człowiek jest najnieszczęśliwszym stworzeniem na ziemi. Homerowy Zeus wymawia takie na przykład słowa:

Biedne konie! Ach, czemuż daliśmy was śmiertelnemu

Człowiekowi, was, co nie znacie starości ni śmierci!

Czy po to, by was uwikłać w udrękę ludzi nieszczęsnych?

Bo przecież ze wszystkiego, co pełza i dyszy na ziemi,

Nie ma, nie ma istoty bardziej nieszczęsnej niż człowiek!

(Iliada, cyt. za: Kubiak 2001: 100)

Może się wydać zaskakujące, ale dla Dygasińskiego celem literatury jest właśnie wywoływanie w czytelniku zasępienia. Wielka sztuka predestynowana jest do tego, żeby odsłaniała człowiekowi nędzę życia. Przy czym gorycz zawsze będzie stanem bardziej szlachetnym aniżeli bezwiedna i pozbawiona refleksji radość: „Jeżeli tylko prawda wywołuje smutek, to nie jest on jeszcze żadną rozpaczą przecież — jest lepszym niż bezmyślna wesołość" (Dygasiński 1884: 529). Cierpkie są przemyślenia Dygasińskiego zwłaszcza gdy zauważa, że jedynym antidotum na tę jasność widzenia jest tłumienie zgorzknienia ciężarem pracy albo fantazmatami:

Geniusze stwarzaja poza obrębem życia arcydzieła, które dodają życiu tylko goryczy, ukazując, że wielkie hasła szczęścia doczesnego są marzeniem niedościgłym. Na tym padole płaczu jedynie ciężka praca daje zapomnienie o niedoli, a marzenie jest wykładnikiem szczęścia ${ }^{14}$.

(Dygasiński 1902: 83)

11 List z 28 I 1895 roku.

12 Uwzględniając znajomość życia i twórczości Dygasińskiego, należy mieć na uwadze również to znaczenie „moralności literatury”, jakie wynika z zasady reprezentowania przez literaturę etyki (pozytywistycznej, chrześcijańskiej), zewnętrznej wobec świata przedstawionego dzieła.

13 Aforyzm ten, i kilka innych, ogłosił pisarz, bez tytułu, w warszawskim tygodniku literacko-społeczno-politycznym „Głos” w końcu 1886 roku.

14 Aforyzmy wyjęte z utworu W Kielcach. Aforystyczność u Dygasińskiego wyraża się często w kilkuzdaniowej refleksji mającej cechy quasi-definicji. Strukturę tak skonstruowanej wypowiedzi organizuje zwykle paradoks, w tym przypadku opiera się on na koncepcie, że istotą dzieła wybitnego jest niesienie takiej wizji świata, która wzmocni u odbiorcy jego stan rozgoryczenia. Opracowanie tego rozpoznania nie odstępuje od stylu ówczesnej felietonistyki i głoszonych w niej potocznych prawd, wykorzystujących ograne frazesy typu: „padół płaczu”, „praca daje zapomnienie o niedoli” czy „,szczęście jest złudne”. 
Był ten sąd Dygasińskiego na tle epoki pozytywizmu dość niekonwencjonalny ${ }^{15}$, co uwydatniał Stanisław Brzozowski, widzący w „beznadziejnym smutku” i poczuciu „bezużytecznego znużenia”, które odczytywał z dzieł pisarza, wartość szczególną. Ze zrozumieniem przyglądał się Brzozowski ucieczce Dygasińskiego w świat przyrody, niespecjalnie łaskawą krytyką natomiast obdarzał autor Legendy Młodej Polski innych twórców współczesnych pisarzowi, którym zarzucał fałsz ideowy wynikający z nierzetelnej analizy rozpoznań czynionych w oparciu o obserwację rzeczywistości oraz własne przeżycia i rozterki duchowe:

Obok niego [Dygasińskiego — przyp. A.S.] znajdujemy pisarzy, których nie stać było albo na tak głębokie wniknięcie w życie, na tak szczere zmierzenie się ze swym smutkiem, albo też na siłę przezwyciężenia choćby tylko osobistego. Obraz życia przez nich przedstawiony nie posiada prawdy wczucia się w treść życiową, o którą idzie. Brak głębokości duchowej wyradza tu pewien kłamliwy i powierzchowny optymizm. (Brzozowski 1959: 231)

Z podziwem dla Dygasińskiego, za jego rozumną postawę w rozpoznaniu fatalnego smutku, lansował Brzozowski tę ideę pisarza, która ocalenie dla człowieka widziała właśnie w sztuce (sic!). Brzozowski miał przeświadczenie, że twórca Margieli dla samego siebie, w swoim pisarstwie taki azyl odnajdywał. To przypuszczenie krytyka z pewnością potwierdzają listy Dygasińskiego, zwłaszcza prywatne, których dominantą jest szczerość wyznania ${ }^{16}$. Najbardziej intymne spostrzeżenia na temat wartości pisania zawarł Dygasiński w korespondencji z córką ${ }^{17}$. Perswadował jej na przykład, że poprzez akt tworzenia, w opisywaniu życia człowiek się „,wychowuje samodzielnie w swoich głębokościach duchowych” (Dygasiński 1972: 517). Przedstawiając walory pracy twórczej, pisarz pozwalał sobie na projekcję zwierzeń także w tonie mniej rzeczowym, ale za to wyraziściej odsłaniającym upodobania i fascynacje:

Jest to [pisanie — przyp. A.S.] coś w rodzaju snów dobrych, marzeń odległych od życia zwykłego; niekiedy można by to nawet porównać z wycieczką w krainy cudowności nadziemskiej.

(Dygasiński 1972: 517)

Tworzenie nie stanowiło dla Dygasińskiego, oczywiście, wyłącznie działania o charakterze przyjemnościowym, jakkolwiek zadowolenie i satysfakcja fundujące się na akcie twórczym czyniły podstawę wszelkiej pracy, której źródło było w wyobraźni: „Pierwszy warunek [pisania - przyp. A.S.] jest ów pociag, co mu się oprzeć nie można, rozkosz, zabawa w swojej własnej robocie" (Dygasiński 1972: 386). Dygasiński wielokrotnie dzielił się z córką (także z przyjaciółmi) przykrymi wrażeniami związanymi z uciążliwością działań

15 Jakkolwiek rozpoznania Prusa czy Orzeszkowej na temat pracy wydać się mogą w pewnym zakresie zbieżne ze spostrzeżeniami Dygasińskiego.

16 List jest formą bardzo pojemną i dość szczególną w przypadku, gdy autorem bywa pisarz — wówczas zyskuje znaczenie jako „dokument biograficzny lub laboratorium twórczości» (Czermińska 1975: 28).

17 Listy Dygasińskiego do córki w dużej mierze aktualizują się w funkcji przyjacielsko-intymnej, przybierają jednak nierzadko równocześnie kształty wypowiedzi parenetycznych (M. Woźniakiewicz-Dziadosz wyodrębniła cztery formy gatunkowe listu: urzędowy, parenetyczny, konwencjonalno-towarzyski oraz przyjacielsko-intymny, zob. Woźniakiwicz-Dziadosz 1998:15). Subtelności logiczne wyłożonych w liście skomplikowanych zagadnień czynią z formy epistolarnej pouczający komentarz utrzymany w tonacji mentorskiej. Jak pisał starożytny teoretyk, „ten, kto przetyka list mądrymi sentencjami i moralnymi zachętami, już nie gawędzi w liście, ale daje wykład zza pulpitu" (Demetriusz 2006: 153). 
pisarskich. Doświadczał kryzysów twórczych i powattpiewał w sensowność żmudnej „roboty”. Mimo apatii, pisał jednak systematycznie. Tworzenie z latami stawało się dla niego doświadczeniem egzystencjalnym:

Do Dębów się zabrałem; idzie to ciężko, a zrobić trzeba: jest mus wewnętrzny, bez którego już widać żyć nie mogę. Nałóg bazgrania! (Dygasiński 1972: 592) ${ }^{18}$

Ten nałóg rozwijał się nie tylko poprzez pracę literacka. Wolno przypuszczać, że równie istotne znaczenie odgrywała w życiu Dygasińskiego twórczość korespondencyjna. Pisywał listy bardzo regularnie, długie do żony i córki, krótsze do znajomych. Miał przy tym pewność, że korespondencja prywatna stanowi wartość wyjątkowego rodzaju. Po pierwsze, ustawiczne pisanie listów kształci umiejętność posługiwania się słowem, po drugie zaś - wyznania czynione w listach prywatnych stają się z czasem, co oczywiste, ważnym dokumentem. Zaliczane do literatury dokumentu osobistego listy dostarczaja m.in. wiedzy socjologicznej i psychologicznej, ponieważ są obrazem duszy nadawcy, a jednocześnie ilustrują środowisko i czasy, w jakich autor ich żyje. To dlatego Dygasiński gorąco namawiał córkę, aby informowała go w listach o wszystkim, o sprawach ważnych i błahych, o odczuciach, spostrzeżeniach i myślach. Z radością przyjmował pomysł Zosi na notowanie codziennych drobiazgów. Pełen emocji utwierdzał córkę w przeświadczeniu, że decyzja, którą powzięła, jest wielkiej wagi:

Wiele wrażeń prześlizga się bez śladu, a Ty je uwięzisz na papierze i zostaną tak dla mnie, jak
dla Ciebie. Pisz tylko szczerze, a bez żadnej pretensji, to będzie przewyborne. Pisz wszystko:
kogo widujesz na ulicy, kogo odwiedzasz, kto do Ciebie przychodzi, o czym mówicie, opowiadaj
o biurze i stosunkach biurowych — zwykłych i niezwykłych. Mało kto pojmuje wartość takiego
archiwowania życia; ale kiedy się zbierze rok okragły, ma to już wartość niepoślednia i stano-
wi kawałek dokumentu życiowego. Znajdziesz w tej robocie jednocześnie i zadowolenie. Nie
pomijaj stosunków z służąca, z dziećmi, z woźnymi biurowymi, tak aby się uwypukliła całość
życiowa, jaką ona jest w rzeczywistości. Notuj, do kogo pisujesz i kto Ci odpowiada, co pisze.
Sam od dawna zamierzałem robić coś podobnego i zawsze spełzło. Toteż cieszę się ogromnie,
że wpadłaś na podobny pomysł. Wspominaj nawet o ubraniu swoim, o najzwyczajniejszych fak-
tach i wypadkach. Zachęcam Cię, Najdroższa moja, nie tylko w swoim własnym interesie, gdyż
przekonasz się sama, jak to pięknie będzie wyglądało, skoro się uzbiera wiązka z całego roku. (Dygasiński 1972: 604-605) ${ }^{19}$

Nie prowadząc dziennika, kompensował sobie Dygasiński ten brak skrupulatnym pisaniem listów, zawierając w nich możliwie dużo szczegółów o warsztacie twórczym, planach wydawniczych, ludziach, których spotykał, podróżach, marzeniach, otoczeniu, w którym przebywał, codziennej monotonii. Nie przeceniał jednak znaczenia listów w pracy pisarskiej. To literatura piękna miała dla Dygasińskiego nieporównywalnie większą siłę oddziaływania: „Wprowadza u człowieka zmiany. Po przeczytaniu książki zaczynamy inaczej kochać, inaczej myśleć" (Dygasiński 1953a: 229) ${ }^{20}$. Dlatego istotne dla niego było to, jakie treści ze sobą niesie dzieło. Rzecz znamienna, że pisarz daleki był od promowania literatury

18 Z listu do córki z 7 II 1901 roku.

19 List z 24 IV 1901 roku.

20 Nie wszystkie aforyzmy Dygasińskiego wyzyskują właściwe dla tego gatunku chwyty antytezy i twierdzeń sprzecznych. Wiele uwag pisarza, ujętych w zwięzłe formuły, nie zaskakuje ani pod względem stylistycznym, ani znaczeniowym. Będąc powieleniem znanych powszechnie myśli, rozważania te bywają dalekie od 
umoralniającej. Dydaktyzm przyjmował jako oznakę mierności. Od dzieła sztuki literackiej wymagał, żeby przede wszystkim było prawdziwe, a to — można się domyślać — znaczyło też ,artystyczne”. Przekonywał tak oto:

Że książka oddziaływa, dowodem werteryzm. Nigdy przez moralizowanie nie doprowadzono by nikogo do tego, aby sobie życie odbierał. Ale czy dlatego, że się ktoś może zarżnaćc, nie wyrabiać nożów i brzytew? - Sztuczne lekarstwa na takie wpływowe książki są też niedobre, gdyż zrażając do marzycielstwa, ośmieszając idealizm łatwo pobudzić młodzież do groszoróbstwa, bogatych ożenków, karierowiczostwa itd. W ogóle autorzy lekarze są lichym żywiołem, ponieważ artyzm zastępuje u nich tendencja ${ }^{21}$. (Dygasiński 1953a: 229)

Identyczność wiarygodnego przedstawienia rzeczywistości z zasada artystyczności dzieła jest konceptem, który wypada skonfrontować z Arystotelesowską teorią mimesis. U starożytnego filozofa znajdujemy przykład, który wyraźnie te pojęcia rozgranicza. W XXV rozdziale Poetyki jest powiedziane, że jeśli poeta podjął się naśladowania, ale nie przeprowadził go należycie ze względu na swą nieudolność — popełnił błąd istotny dla sztuki poetyckiej. Jeśli natomiast przedstawił coś niewłaściwie, jak np. konia, który jednocześnie podnosi obie prawe łapy, lub coś, co byłoby błędem z punktu widzenia medycyny albo jakiejś innej sztuki — jego błędu nie można zaliczyć do wykroczeń przeciwko sztuce poetyckiej (Arystoteles 1989: 93). Inaczej rzecz przedstawia się u Dygasińskiego. Klarownie to wykłada pisarz w jednym z listów do córki (z 28 I 1895 roku), formułując wypowiedź w rodzaj instruktażu objaśniającego prawidła pisania:

Zupełnie to obojętne, co się robić przedsiębierze: bajka dla dzieci, list do kogoś, opis miejsca, obraz jakiego zdarzenia. Gdy to idzie naprzód, gdy myśli płyną i gdy się o tym jednym tylko myśleć musi, to dobrze. Weź dwie kobiety, młode pensjonarki, gdy jedna drugiej z cała szczerością, naiwnością opowiada, że oprócz matki, ojca, sióstr i braci kocha jeszcze kogoś. Ale to zrób z prawda, abyś sama prawdę uznała i aby ją każdy uznał. Mniejsza o styl; stylu na świecie nie ma, jest tylko myślenie, uczucie, odczuwanie świata i wyrażanie tego na zewnątrz. Weź trzy kobiety, które wieczorem przy herbacie przypinają bliźnim łatki. Zrób to tak, jak one robia, ich stylem, ich spojrzeniami, ich ruchami, fizjognomia, ubiorem, wszystkim, co w nich jest. Jeśli to umiesz odczuć, podpatrzeć i potrzebujesz wyrazić na papierze, to dobrze, to tak. Weź matkę, która jedyne dziecko straciła. Jeśli z nią potrafisz płakać, czuć jej żal, jeśli możesz to wszystko łatwo wyrazić, jeśli myśląc o tej scenie masz błyski uczucia i myśli, jeśli Ci się narzucają różne okoliczności, którymi te myśli i uczucia można dobrze oświetlić, wycieniować, to dobrze, rób! Rób zreszta, co chcesz: siebie samę, gdyż siebie samę masz pod ręką zawsze; ale rób się bezpretensjonalną, nie dlatego, aby sie przedstawić, tylko — aby się zrobić w portrecie rzetelnym, prawdziwym. Rób naturę, tylko nad nią zbyt po ludzku nie czuj, nie ubolewaj, gdyż w niej tego nie ma; ona jest sama soba, inną od naszych książkowych wyobrażeń. Rób fantastyczne bajki, ale je twórz: niech przed Tobą stają anioły lub potwory, które przedstawiasz; powinnaś widzieć, jak one pokazują zęby gdy się śmieja jak się wykrzywiaja gdy płaczą, jak im się oczy iskrza, jaką barwę i połysk barwy twarze ich mają. Zrób jedno, drugie, trzecie, a gdy się robota stanie potrzeba, gdy myśli poczną się koło głowy roić jak pszczoły, to dobrze, to rób dalej i rób, a rób!

(Dygasiński 1972: 385-386)

odkrywczości, niemniej — warte uwagi ze względu na potrzebę odtworzenia systemu wartości i wyznaczników estetyki owej osobliwej działalności pisarskiej.

21 Przykład ten świadczy, że aforystycznie ujęta myśl (tu: ostatnie zdanie cytowanego fragmentu) funkcjonuje u Dygasińskiego także niesamoistnie i może być w pełni zrozumiała tylko w obrębie kontekstu — podobnie jak w twórczości Aleksandra Świętochowskiego (zob. Mazan 1994: 173-185). 
Okazuje się, że jakkolwiek w obu przypadkach „mimetyczny” znaczy tyle samo, co „artystyczny", to jednak kategoria mimesis znaczyła dla Dygasińskiego co innego niż dla Arystotelesa. Różnica tkwiła przede wszystkim w tym, że klasyk dawał przyzwolenie na zamieszczanie w dziele rzeczy nieprawdopodobnych ${ }^{22}$ (Arystoteles 1989: 94), tzn. sprzecznych z rozumem i faktycznym stanem rzeczy, pozytywistyczny twórca natomiast naśladowanie kojarzył z wiernym odtworzeniem świata rzeczywistego. Dygasiński radził koncentrować się na szczególe (podpatrzonym), zalecał ścisłą obserwację i rzetelne odwzorowywanie spostrzeżeń w słowach. Nie negował obecności w literaturze istot nadnaturalnych (choć zakres ich bytności zawęził do fantastycznych bajek), domagał się jednak, żeby wyobrażenia te były wyraziste, konkretne, plastyczne, czyli prawdopodobne — aby nie burzyły iluzji rzeczywistości. Postulat prowadzenia wnikliwych studiów zmierzających do odtworzenia prawdy, połączony z koncepcją człowieka fizjologicznego, w jego naturalnych odruchach, instynktach, emocjach, bez idealizacji — to oczywiście wyznaczniki naturalizmu. Podstawowe założenia tej poetyki Dygasiński realizował w swoim pisarstwie wytrwale, choć nierzadko dawał przykłady innych inspiracji. Był zdania, że naturalizm należy łączyć z konsekwencją społecznych przeobrażeń i rola jego w rozwoju historycznym literatury, jak też w ewolucji społeczeństw jest nie do przecenienia:

Piśmiennictwo malując życie — twierdził Dygasiński — nikogo nie gorszy, a tylko budzi sumienie publiczne. Ono jest spowiedzią publiczną. Łotrów, prostytutki tworzy życie, a literatura ujawnia, że sa.

I kontynuował, forsując ideę, którą szczerze i z entuzjazmem promował, a nigdy się jej nie sprzeniewierzył:

Dziś lud na porządku dziennym i musi być społeczna literatura ludowa. Literatura ma epoki: róż, słowików, chłopów, szlachty itd. Literatura musi zrobić chłopa, pokazać, czym on jest.

(Dygasiński 1953a: 223)

Na temat krajoznawstwa, ludoznawstwa i potrzeby tworzenia literatury ludowej Dygasiński zabierał głos często w tekstach publicystycznych. Znaczące są zwłaszcza artykuły drukowane w „Wędrowcu” w 1886 roku: Krajowa praca (nr 19, 20) i Jesz̨z̨e o pracy krajowej (nr 24) oraz w „Kurierze Codziennym” w 1885: Chłopska ragroda (nr 73, 110, 136).

Aktywność publicystyczna zaangażowana w popularyzację idei literatury ludowej, czy szerzej — społecznej, nie pozostaje w sprzeczności z traktowaniem sztuki jako ideału, którego doniosłością „definiuje się” sam twórca. Sztuka otwiera pisarzowi możliwość doświadczania wyjątkowego stanu — wyzwolenia. Dygasiński czuł, że dzięki tworzeniu przezwyciężał ograniczenia. Pisząc i żyjąc w świecie literatury, odnosił wrażenie przekraczania granic wyznaczonych na istnienie zwykłemu człowiekowi. Wierzył, że są „liczne sposoby tworzenia i kto tworzy, jest wolny" (Dygasiński 1953a: 227) ${ }^{23}$. Paradoksalnie — doznawał za sprawą tej wspartej na autopsji wiedzy uczuć przykrych. Miał świadomość, jak wysoka cenę płacił za swą wolność. Dawał temu wyraz w intymnych listach do żony i córki, które

22 Autor Etyki nikomachejskiej powiada, że „mniejszy to przecież błąd, jeśli artysta nie wie, że sarna nie ma rogów, niż jeśli ją przedstawi w sposób nienaśladowczy”, tj. niezgodny z zasadami sztuki, czyli nieartystyczny. Wypowiedzi Dygasińskiego poświęcone literaturze i psychologii twórczości warto skonfrontować z rozważaniami Henryka Sienkiewicza na temat niekoniunkturalności działań artystowskich i wolności pisarza (por. Żabski 1979: 190-192). 
kochał bezgranicznie, a oddalał się od nich z powodu sztuki. Nawet gdy posady guwernerskie, jakie przyjmował w prywatnych domach ludzi możnych, oferowały mu rozgoryczenie (a były dla jego rodziny podstawowym źródłem dochodu), cenił niepomiernie spokój i samotność, które tam odnajdywał i mógł pożytkować na pracę twórczą. Z tej przyczyny nieustannie też błagał swoje kobiety, żonę i córkę, aby zechciały mu przebaczyć jego egoistyczną potrzebę odosobnienia. Zaklinał, przepraszał i prosił o wyrozumiałość dla siebie. Dramatycznie przeżywając nierozwiązywalne antynomie życia, był Dygasiński człowiekiem autentycznie smutnym, a w smutku swym bardzo delikatnym. Zważywszy na jego własne rozpoznanie mówiące, że warunki, w jakich żyje autor, oddziaływają na koloryt dzieł, fakty te bez wateienia rzutują na oblicze pesymizmu, który twórczość jego znamionuje, wyznaczając jej miejsce w bliskości modernizmu, a z dala od idealistycznych złudzeń romantycznych. Jest to niewątpliwie pesymizm o potężnej sile, choć „wypracowany” z użyciem skromnej ludzkiej miary. Cóż bowiem miał Dygasiński do powiedzenia np. o „namaszczonym” romantycznym obowiązku cierpienia za miliony? „Niech mi wolno będzie - wyjaśniał autor Zajaca - powiedzenie takie nazwać jednak przesada. Nawet największy człowiek może cierpieć tylko własnym sercem i cierpieć za siebie" (Dygasiński 1953a: 222). Odejmując człowiekowi patos budowany na utopijnych fasadach, pisarz projektował człowieka nowoczesnego — z piętnem smutku i naznaczonego lękiem metafizycznym ${ }^{24}$. Nie godził się, by jakość nowego człowieka kształtowała literatura górnolotna, której istotę określała treść wsparta o nierzeczywiste pojęcia i nierzeczywiste uczucia. Poezja, pouczał Dygasiński, nie może być niedorzecznością ${ }^{25}$. Jej zadaniem jest obserwacja realnego porządku (chodziło tu zwłaszcza o obiektywne wniknięcie w życie ludu (Dygasiński 1886b: 517), nie zaś nadzwyczajność uczuć i woli.

„Antyromantyzm” projektu pisarskiego Adolfa Dygasińskiego ujawniał się także w tym, że pisarz był rzecznikiem literatury świadomej. To, co powstawało w natchnieniu, nie mogło być podawane w utworze w wersji pierwotnej, czystej, „improwizowanej”. Każdą myśl należało starannie opracować: „Nic nie szkodzi — pouczał córkę — gdy się jedną rzecz trzy i cztery razy napisze" (Dygasiński 1972: 390) ${ }^{26}$. Tajniki własnego warsztatu autor Godów sycia odkrywał w szczegółach. Miał zwyczaj notowania wszelkich myśli, które później wielokrotnie przekształcał, starając się ująć je w coraz lepszą formę językową. Wysiłki językowe zmierzały do nadania pomysłom zwięzłego, jasnego i możliwie dobitnego wyrazu. Ideałem była dla niego oszczędność wysłowienia - ścisłość i dosadność, jaką znajdował u Reja, Skargi i Wujka, jak w takich zdaniach, które z upodobaniem cytował córce: „Koniem żartkim nie tyka ziemi” lub „Winem wybili sobie z głów fatygi” (Dygasiński 1972: 390). Nie zawsze, naturalnie, mógł dochować wierności zasadzie operowania językiem „zdyscyplinowanym”. Konieczność pisania zarobkowego, pośpiesznego, powodowała, że efekty pracy twórczej bywały różne.

\footnotetext{
24 Świadectwem tego m.in. opowiadanie Demon (por. Gloger 2009; Skała 2013: 192-204). przeprowadził pisarz, recenzując wiersz pt. Pieśn íncia autorstwa Klemensa Podwysockiego, drukowany w „Tygodniku Ilustrowanym” 12 VI 1886 (Dygasiński 1886a: 299-300). 
Jeśli przyznawał Dygasiński sztuce literackiej rangę wyższą niż życiu społecznemu, to z pewnością w hierarchii bytów sytuował ją niżej niźli świat natury ${ }^{27}$. Sądził mianowicie, że „prawdziwe piękno i prawdę tworzy tylko przyroda, a człowiek o tyle, o ile jest istotnie wybrańcem przyrody, godnym, aby ja reprezentować i w jej imieniu tworzyć arcydzieła" (Dygasiński 1884). Gdyby przyszło wyprowadzać wnioski dotyczące wartości pisarstwa Dygasińskiego w oparciu o tę jego metodę oceny literatury (porównawczą względem dzieł natury), nikt nie odmówiłby mu zapewne miana „wybrańca przyrody”. Ideę przenikania w głąb natury urzeczywistniał w całym swoim dziele. Ewidentne jest, że ów plan realizował skrupulatnie, z niebywałą wrażliwością — jak chyba żaden inny twórca ${ }^{28}$. Wolno sądzić, że także ci, którzy niechętnie sięgaja po dzieła Dygasińskiego, daliby się usposobić przychylnie do tej formuły. Z pewnościa przekonywającym mógłby okazać się już taki opis lasu, iglastego i liściastego:

Bór iglasty! Oto stoi uroczyście w wyprostowanych kolumnach sosen, jodeł, świerków, modrzewi, jak gdyby celem tej społeczności żywej było uczczenie ciszą grobów. Pachnie żywicą i zaledwie znosi w dziedzictwie swoim istoty liściaste: borówkę, paproć, wrzos sztywny albo te szarozielone roślinki omszone włoskami, a mające listki jakby przybite do ziemi. Cichy w swych padołach, uroczyście szumiący w szczytach stoi las jak cmentarz, zasłany igliwiem obumarłym, gałązkami uschłymi, szyszkami, a podłoże jego gnie się pod stopami niby trzęsawisko. Chodzi się tutaj po cichu...

Ogromnie poważna cisza tu panuje... Rzecz dziwna, jak ją śmie zakłócać dzięcioł tak głośnym kuciem w drzewo albo sójka krzykiem nagłym, chrapliwym, wiewiórka fukaniem i zgiełkliwym pierzchaniem kędyś ku szczytom. (...)

Z krainy posępnego milczenia, w jakie przyoblekają przyrodę igły i szyszki, przejdźmy do drugiej komnaty boru, która połyskuje świetnością, drga weselem życia. Jakże tu pięknie, ile tu szczęścia przez całe lato! Co to za dęby, jakie buki, wiązy, jesiony, klony, lipy, brzozy! Tam mogłeś się był modlić, a tu, w tej dąbrowie rozkosznej, zdejmie cię chyba chęć do pląsów. Sosna, świerk czy modrzew, jeżeli się tu gdzie i znajda, wyglądaja jak osoby stanu duchownego, które przybyły w gościnę na wielką salę godową i nie zamącą powszechnej wesołości. Murawa haftowana w kwiaty różnowzore, różnobarwne podesłała się pod ten świat piękny, pełen życia soczystego, w którym czuć wyraźnie, jak tętnią potoki obfite krwi zielonej.

O, to już nie lepka limfa żywiczna, płynąca w suchych drzewach szpilkowych! (..)

Tam było parno, duszno, żywicznie wonno jak w kościele na nabożeństwie uroczystym; tu przez całe lato skwarne panuje świeżość orzeźwiająca z tych pereł i brylantów rosy, cudnych łez, które boleść czy radość wyciska z ziemi o zmroku i o świtaniu.

Firletki, bodziszki, konwalie, storczyki, goździki, sasanki, koniczyny, poziomki, cieciorki, groszki i róże dzikie, i głogi, i kaliny — malowanki prześliczne. (Dygasiński 1952: 66-68)

27 Warto mieć jednak na uwadze fakt, że natura jest przez pisarza pojmowana ambiwalentnie. Złożoną filozofię Dygasińskiego budowaną na refleksji o niszczącej człowieka sile przyrody objaśnił Zygmunt Szweykowski, dokumentując swymi rozpoznaniami antynomiczność twórczości autora Beldonka (Szweykowski 1938).

Spośród pozytywistów jeszcze Elizę Orzeszkową wyróżnia szczególna czułość dla świata przyrody. Ale, jak zauważa badacz tej twórczości, zoologia i ornitologia zajmują w jej utworach mniej miejsca niż botanika (Budrewicz 2012: 33). Pisarstwo Orzeszkowej nie poświadcza takiego sposobu prezentowania zwierząt i „sympatycznego” wnikania w ich psychikę, który prowadziłby, jak u autora Beldonka, na przykład do kształtowania narracji z perspektywy zwierzęcej (psiej, oślej albo zajęczej). Nie bez powodu Dygasiński został uznany za „rewelatora psychologizmu zwierzęcego” — określenie J.E. Płomieńskiego (Płomieński 1939). Niewątpliwym jest jednakże fakt, że oboje pisarze, Dygasiński i Orzeszkowa, byli zaangażowani (niezależnie od siebie) w tworzenie tego, co Tadeusz Budrewicz określa „,mitem ziemi rodzimej i moralnego obowiązku pracy dla niej" (Budrewicz 2010: 252). 
Przedstawiony opis pełni funkcję liryczną — jak w powieści młodopolskiej (Budrewicz 2010). Ale nie ma w nim jeszcze tego (cytat jest fragmentaryczny), z czego pisarstwo Dygasińskiego słynie: w leśnych ostępach zawsze panuje niebywały ruch wszelkich stworzeń - są owady, ptaki i inne zwierzęta. Autor Zajaca nie tylko analizował zachowania przedstawicieli różnych gatunków fauny i ekspresywnie ten behawioryzm prezentował, ale też dawał przykład, że na rzeczywistość można patrzeć z perspektywy innej niż ludzka.

\section{Bibliografia}

Arystoteles (1989), Poetyka, przeł. H. Podbielski, BN II 209, Zakład Narodowy im. Ossolińskich, Wrocław.

Bielak Franciszek (1925), „Ostatnia wyprawa Albertusa”. Nieznany utwór Adolfa Dygasińskiego, odbitka z „Exlibrisu”, Kraków.

Brzozowski Stanisław (1959), Powieść „mieszrzanska” i jej fazy u nas [w:] Polska krytyka literacka (1800-1918), t. IV, red. J.Z. Jakubowski, PWN, Warszawa.

Budrewicz Tadeusz (2010), Eaki Orzeszkowej [w:] Małe prozy Orzeszkowej i Konopnickiej, red. I. Wiśniewska, B.K. Obsulewicz, Towarzystwo Naukowe KUL, Lublin.

- (2012), Ptaki Orzeszkowej [w:] Sekrety Orzeszkowej, red. G. Borkowska, M. Rudkowska, I. Wiśniewska, IBL PAN, Fundacja Akademia Humanistyczna, Warszawa.

Chmielowski Piotr (1904), Jeszcze o celu w sæ̨tuce, „Pamiętnik Literacki”, nr 1/4, t.3.

- (1872), Utylitaryzm w literaturze, „Niwa”, nr 18.

Czachowski Kazimierz (1939), Dygasiński w naszych oczach, „Kurier Literacko-Naukowy”, dodatek do „Ilustrowanego Kuriera Codziennego”, nr 10.

Czermińska Małgorzata (1975), Pomiędzy listem a powieścia, „Teksty”, nr 4.

Demetriusz (2006), O wyrażaniu sie [w:] Tray stylistyki greckie: Arystoteles, Demetriusz, Dionizjusz, przeł. W. Madyda, Ossolineum, Wrocław.

Dygasińska-Wolertowa Zofia (1932), Adolf Dygasiński. Z teki pośmiertnej. W 30-lecie agonu autora „Godów syycia”, „Tęcza”, nr 7.

Dygasiński Adolf (1884), [incip.:] Obserwacja artysty ma ten sam cel..., „Przegląd Tygodniowy”, nr 46.

- (1886a), [incip.:] Każdy utwór sz̨tuki..., „Przegląd Tygodniowy”, nr 25.

- (1886b), [incip.:] W modzie jest dzisiaj traymaí z. ludem..., „Przegląd Tygodniowy”, nr 46.

- (1902), Aforyzmy pedagogiczne, „Miesięcznik Pedagogiczny”, nr 7-8.

- (1952), W Kielcach [w:] tegoż, Pisma wybrane, red. B. Horodyski, t. XIII, Ksiażka i Wiedza, Warszawa.

— (1953a), Aforyży o s̀ciu i literaturze [w:] tegoż, Pisma wybrane, red. B. Horodyski, t. XXIV, Książka i Wiedza, Warszawa.

- (1953b), Myśli [w:] tegoż, Pisma mybrane, red. B. Horodyski, t. XXIV, Książka i Wiedza, Warszawa.

- (1972), Listy, wstęp J.Z. Jakubowski, koment. A. Górski, red. tech. T. Nuckowski, Zakład Narodowy im. Ossolińskich, Wrocław. 
Gloger Maciej (2009), Adolf Dygasiński i narodżiny nowoczesnej świadomości narodowej, „Litteraria Copernicana", nr 2.

Korespondencja Antoniego Sygietyńskiego i Piotra Chmielowskiego. Dwuglos z. lat 1880-1904 (1963), oprac., wstęp i komentarz E. Kiernicki, Zakład Narodowy im. Ossolińskich, Wrocław. Kubiak Zygmunt (2001), Pobojowisko [w:] tegoż, Pótmrok ludqkiego świata, Znak, Kraków.

„Litteraria Copernicana” (2009), nr 2 [tom poświęcony Adolfowi Dygasińskiemu].

Markiewicz Henryk (2002), Pozytywizm, wyd. 6, Naukowe PWN, Warszawa.

Mazan Bogdan (1994), Aforystyka stosowana praywódcy „Mtodych” — „ksiażka” pokoleniowa in statu nascendi [w: Ksiażka pokolenia. W kregu lektur polskich doby postyczniowej, red. E. Paczoska, J. Sztachelska, Wydawnictwo „,Luk”, Białystok.

Płomieński Jerzy Eugeniusz (1939), Problematyka ludowa w twórczości Adolfa Dygasińskiego, „Radostowa", nr 1-2.

Podlewski Ryszard (2006), Rok z Vat-em, Wydawnictwo Bestprint i Wielkopolska Agencja Literacka Wal Art, Lublin-Poznań.

Skała Agata (2012), Sacrum w „Godach sycia” Adolfa Dygasińskiego. O niepozytywistycznym prayrodoznawstwie i irracjonalizmach, „Pamiętnik Literacki”, nr 1.

- (2013), Adolf Dygasiński — niepoprawny posytymista. Międry tradycja a nowoczesnościa, Wydawnictwo UMCS, Lublin.

Szweykowski Zygmunt (1938), Dramat Dygasinskiego, Nakład Gebethnera i Wolffa, Warszawa.

Woźniakiewicz-Dziadosz Maria (1998), Obrzeża formy powieściowej, Wydawnictwo UMCS, Lublin.

Żabski Tadeusz (1979), Poglady estetyczno-literackie Henryka Sienkiewicza, Zakład Narodowy im. Ossolińskich, Wrocław. 